\title{
Meritocracy, social mobility and a new form of class domination
}

Abstract: meritocracy is used by governments in many societies as an 'effective' way to represent social justice and legitimise - explain away - class inequality. By focusing on a small number of working-class students who achieve academic 'success' and have reached elite universities in an ideal meritocratic environment - Chinese schooling this paper aims to discuss the relation of meritocracy to upward social mobility and class domination. Our analysis raises questions about the notion of 'success' in a meritocratic environment and suggests the operation of a new form of symbolic domination in relation to these working-class high-achievers. Through their 'successes' at school, they are distanced from their working-class localities and histories, while they also remain outside of the middle-class sensibilities that they aspire to - they become a 'third class' whose core values reside in meritocracy itself. There is no transcendence of class here rather a different form of distinction and exclusion.

Keywords: meritocracy; social mobility; Bourdieu; working-class students at elite universities; China

Word count: 7,827 words (including the abstract and bibliography)

\section{Introduction}

And to give them that, we should take this opportunity to step back and pose a fundamental question: what kind of country - what kind of society - do we want to be? I am clear about the answer.

I want Britain to be the world's great meritocracy - a country where everyone has a fair chance to go as far as their talent and their hard work will allow.

I want us to be a country where everyone plays by the same rules; where ordinary, working class people have more control over their lives and the chance to share fairly in the prosperity of the nation.

And I want Britain to be a place where advantage is based on merit not privilege; where it's your talent and hard work that matter, not where you were born, who your parents are or what your accent sounds like.

(DfE, PMO, and May 2016) 
The above quote comes from the speech delivered by UK Prime Minister Theresa May in December, 2016 titled 'Britain, the Great Meritocracy'. Two issues - social justice and upward social mobility - are at the centre of this speech. The first addresses the fairness of distribution of resources between social classes and the latter asserts the virtues of an open society. As clearly shown in May's speech, meritocracy is taken as an effective solution to both these issues. This kind of meritocratic rhetoric is not uncommon and similar examples can be found in countries around the world. A simple Google search provided examples from the US, Singapore, Israel, Russia, Lebanon, Sweden and China. Global neo-liberalism, with its emphasis of the 'global war for talent', gives further credence to meritocracy as a key feature of the lexicon of contemporary education policy (Brown 2009). However, the question is can meritocratic education systems bring about a fairer and better society as many governments claim? Based on a life-story study of a small group of young people who succeed in achieving a certain degree of upward social mobility in a prime meritocratic environment - working-class students attending elite universities in China, we aim to explore in this paper how meritocracy relates to and reinforces class domination.

Meritocracy is an ideology of social justice that is based on the notion of equality of opportunity. It assumes that social justice can be achieved as long as everyone has an equal opportunity to compete for social resources on the basis of merit, rather than by inheritance or wealth. In terms of the understanding of merit in this sense, Young, in his 1958 satire The Rise of the Meritocracy, offered the formula, 'merit = intelligence + effort'. This definition is now widely accepted as the essence of meritocracy, stripped of its satirical and critical intent, as Theresa May vividly described, 'it's your talent and hard work that matter, not where you were born, who your parents are or what your accent sounds like' (DfE, PMO, and May 2016). 
Unequal outcomes are translated into and explained as differences in individual capacities' (Karabel 2005; Reay 1998). Yet, merit is not an inherent personal quality but a set of social produced capabilities underpinned by capitals of different sorts, which ensures that social groups with wealth and heritage, and relevant cultural knowledge and social relations can respond to educational opportunities to assert or reproduce social and economic advantage. In this sense, as many authors have commented (e.g., Dench 2006; Halsey 2007; Sayer 2005), meritocracy is a 'displacement of one principle of stratification by another, of achievement for ascription' (Bell 1973, 391). As Brown (2009) puts it, meritocracy will build a society in which "the "best and brightest" are enabled to rise to the top while the rest can legitimately left to fall off behind' (389). The deployment of individualistic explanation of outcome differences makes social inequality more difficult to recognise and challenge. Many studies (e.g., Brown 2013; Norman 1987; Radnor, Koshy, and Taylor 2007; Young 2001) have proffered critiques of the illusion of social justice based on meritocracy by pointing out the many ways in which structural inequalities are disguised or discounted by the notion of equality of opportunity.

This study is based on meritocracy in action in the Chinese education system, in which access to elite schools ('key schools' ${ }^{\text {1 }}$ in Chinese language) and to elite universities is almost exclusively based on exam performance, or in other words, the outcome of intelligence + effort. The data drawn on in this paper comes from a life story study undertaken between March, 2015 and December, 2017. Three-rounds of life story interviews were conducted with 17 working-class students at four elite universities in China: Fudan University, Peking University, Shanghai Jiao Tong University and Tsinghua University. Some onsite observations were also done and documents were collected. Participants were recruited from final year undergraduate students who had received National Student Loans

\footnotetext{
${ }^{1}$ Schools are divided into key schools and normal schools in China; key schools (including primary schools, junior secondary schools and senior secondary schools) receive more government funding and policy support, have the best teachers and recruit the best-performing students in every level of entrance exams.
} 
(needs-based loans for low-income students at university) and we checked their parents' occupations, income and education levels, their place of birth and their self-identification in the interviews. These accounts were compared with national statistics and with Lu's (2002) analysis of social classes in China. Instead of referring to 'poor students' or 'low-income students', we borrow a western term and use 'working-class students' to refer to the participants. Thinking in class terms offers a more comprehensive understanding of their 'disadvantage' not only in economic terms but also in social and cultural terms. In addition, the participants include both rural and urban 'working-class' students. An 'Informed Grounded Theory' (Thornberg 2012) approach was used to analyse data, with Bourdieu's theoretical tools, habitus, capital and field as the primary sensitising concepts. 'Western' class tools are not imposed on this relatively new context in terms of researching class inequalities in education; rather they are used reflexively to establish dialogue with the literature, make imaginary connections, explore some less obvious forms of domination, challenge our 'biases' and extend our 'sociological gaze' (Bourdieu and Wacquant 1992, 36). Compared with the theory of 'disadvantage', this study aims to achieve 'a theory of advantage' - 'an explanation of inequality that focuses on the resources and strategies of the successful' (Ball 2011, 960). Bourdieu refers to 'the successful' as 'exceptions' (Wacquant 1993, 30) or 'deviants' (Bourdieu 1996, 184) - people who find themselves at 'the pole opposite to the position to which they were promised and which was promised to them' and who are 'undoubtedly one of the most important factors in the transformation of the field of power' (Bourdieu 1996, 184). This study addresses a group of such 'exceptions' and we seek to make sense of their exceptionality - and we ask whether these working-class exceptions are able to transcend class domination, at least to some extent, by their access to and experience of elite university education? A small number of studies have considered the experience of such students in other national settings and in China as well. For example, 
Granfield (1991) conducted a study of working-class students at an elite American law school and Reay and her colleagues (Reay, Crozier, and Clayton 2009), and Hurst (2010) and Lehmann (2013) have explored the experience of working-class students at elite universities respectively in the UK, USA and Canada. Li (2013) published an article regarding rural students at an elite university in China and Xie (2016) undertook a study of working-class students at four elite universities in China using mixed methods. In the later discussion of this paper, we will examine the relation of our analysis to these studies. However, compared with these studies, we intend not only to understand how these working-class students transcend class domination (Bourdieu 1984), that is how they become exceptions, but also explore the role of meritocracy, as a form of educational experience, in shaping the aspirations and possibilities of these exceptions. We want to understand the complex relation between meritocracy, class domination and human agency. Does meritocracy offer the 'brightest' of working-class students opportunities to escape class domination through their 'merit'? Our response to this, the argument developed in this paper, is that meritocracy does not enable these working-class students to transcend class domination but rather it translates upward social mobility into another form of symbolic class domination.

We organise our discussions around two aspects: habitus and field. From the aspect of habitus, we will discuss how and why our respondents become 'exceptions' and from the aspect of field, we will discuss how their experience at key schools reinforces their habitus. Through the interplay of habitus and field, they achieve, as we suggest, the status of 'a third class' - distanced from both their working-class localities of origin and the middle-class destinations to which they aspire, being trained as and transformed into 'meritocratic agents'. 


\section{Habitus: new identity and distancing}

Figure 1 shows the categories we construct in relation to the habitus of these 'exceptions'. These students focus themselves on examination performance driven by two kinds of forces: progressive forces of pursuit and regressive forces of escape, both of which involve strong personal commitment to meritocracy. Their educational 'successes' accumulate a new identity, that of 'the high-achieving student', which evolves alongside and to some extent over and against an existing and 'natural' working-class identity. As the students invest in and seek to maintain their new identity, they come to embody a set of dispositions: industry, strategy, determination and self-discipline among others. These dispositions are articulated as and construct an educational experience formed by individualism and performanceorientation.

[Insert Figure 1 here]

\section{New identity: distancing from working-class localities}

Progressive forces of educational achievement constitute for these students a complex of ambition, self-worth, recognition, rewards and personal interest. This is evident in Da Tang's account:

I was different (from other kids nearby). We saw whether a kid was clever or not from whether he/she could talk nicely, whether he/she could respond quickly. I was surrounded by clever kids, (but I was not clever). When I was doing one thing, I would forget other things, I was very single-minded. For example, when I was watching TV, I couldn't hear anything others said to me. It seemed I was very dumb and stupid. I couldn't do (things they could), swimming, climbing trees. All I could do was to study...I liked mathematics very much. I liked solving questions in textbooks. I was often so dedicated to it until I realised it was very late...I was emulative. My teachers commented that I was 'emulative'. I didn't know what 'emulative' meant at that time, but I knew I should be better than others. If I met someone who was good, I would try to 
find ways to be better. I was like that since I started school, from kindergarten. We could get a certificate of honour if we got full points. I got certificates very often. My parents would praise me, saying I was clever. It was important to get praise in your childhood.

Da Tang accounts for himself as the ambition to excel, to 'be better than others', but the only thing he could excel at was academic performance at school. He was not defined as 'clever' in the terms of the folk norms in his village, he did not 'talk nicely' or 'respond quickly', and yet his academic performance at school singled him out as a 'clever' student. A similar childhood story of having an 'introverted personality' and being distinguished by schoolwork is seen in the other participants' accounts. Like Da Tang, academic performance at school defines their 'worth' and builds their confidence, while the recognition and rewards they acquire on the basis of academic achievement at school, scholarships, praise from parents, popularity among classmates, encouragement and extra care from teachers, enhance their self-identification with the high-achieving student identity and motivate them to invest more of themselves in the maintenance of this identity.

The recognition they gain from academic performance at school is important to them, especially considering the sense of inferiority they feel as working-class students. Recognition as a high-achieving student provides a sense of personal efficacy and builds their 'self-worth', as reported by Yun Jiang:

I really need a sense of relevance. I need to get attention. But meanwhile I was very afraid of being looked at. It was a sense of strong inferiority. It may be influenced by my family background. I felt inferior in speaking, eating, my behaviours, and dressing. People spoke Mandarin (but I spoke the dialect). And, you know, in the English class, I felt really inferior. I was around the twentieth and thirtieth in the grade. No one cared about me. I was very upset. When the mathematics teacher paid attention to me, I felt I was paid attention. I can't remember why I became a high-achieving student, but that teacher (her mathematics teacher) played a significant role. 
With the contrast between a sense of inferiority as a working-class student and a sense of superiority brought about by excellent performance at school, being high-achieving becomes 'the purpose to live in the world' for our respondents. It becomes a 'label', a 'mark' and an 'imprint' for them, as described by Yue Gu:

\begin{abstract}
Working hard on studies is a path of dependence. If you were a good student in people's eyes and they liked you because you were a good student, you would then have the pressure of avoiding going down. Being a good student became a label, a mark, an imprint. If you have an imprint, you will work hard for it. Everyone has a purpose to live in the world (being high-achieving is my purpose).
\end{abstract}

Achievement at school becomes a path of dependence and increasingly defines who they are. This new identity evolves to become their 'primary' identity, and distinguishes them from other working class students. Meanwhile they eschew and deliberately distance themselves from their working classness. They reported a sense of frustration, discomfort and even hatred towards their working-class origins, as shown by Zhen Liang's account:

\begin{abstract}
Childhood experiences had a huge impact on me. People in the village felt envious and uncomfortable at everything good you did for yourself. My parents were building our house. Some people then came and fought with my parents. It was disgusting. I didn't want to live like that. First they were poor economically and also they were poor intellectually. I felt sick to live in the community of these people. I was eager to escape from them. How could I achieve the escape? Through schoolwork. That's why I worked so hard (he said he was the most hard-working student at school).
\end{abstract}

To leave behind class origins and possibilities is thus both a pursuit and an escape. The basis for achieving both is by working hard towards academic performance. However, in practical terms, their dependence on the exam performance is not entirely their 'choice', but is, as they see it, the only alternative to the deprivations and limitations of a working class future, as reported by Yun Jiang below. They have no alternative - who else can they be, what else can they choose? 
I had no computer, no smartphone. The only thing I could do was to study. I also worked on a farm and picked in the paddies. People in the village often said I was so capable, being able to manage both studies and farm work. But I really want to say, I had to (manage both), OK? My mom often told me, if I wanted to change my life, I had no one to count on but myself.

Working on the new identity is a 'choice' that is made up of rational evaluation and planning, imagined futures, emotions and injuries. This is not some much a break but rather an intertwining of old and new. The habitus of our respondents is in some ways similar to what Bourdieu calls a 'divided habitus', that is, 'a habitus divided against itself, in constant negotiation with itself and its ambivalences' $(1999,511)$. The participants in our study are divided and torn between self-fulfilling aspirations, which pull them to be 'extra-ordinary', and a working class identity, which constantly reminds them of their 'ordinary' working class position. These divided 'selves' are in constant tension but intertwined. The awareness of a lack of resources associated with being working class motivates their ambition, drives their need for recognition and constrains their sense of self-worth at the same time. Being working class, but no longer wanting to be working class, they have no alternative but to rely on academic performance for the pursuit of self-worth and recognition. Their working class background defines the way they can leave, the exit they can take and the possibility of being different. Being working class is part of their new identity - it does not disappear despite their attempts to leave it behind.

\section{Dispositions: distancing from middle-class sensibilities}

On the one hand, for these young people, building a new identity involves dispensing with and giving up on some aspects of who they are, while on the other hand the strategy they use to achieve their new identity also distances them from middle-class students. Hard work is at the centre of their strategy. Single-minded and determined industry towards high levels of 
academic performance is the main characteristic of their engagement with school, as illustrated by Jia Peng:

Everyone was out on Saturday evenings except me, still sitting in a big classroom, reciting History and Politics. I got very good results in the final exam of that year. It was the most unforgettable time for me. We had extra classes in summer until 31 July and then we had a break from 1st to 24th August. But I got the key to the classroom from our teacher and then I went to the classroom and studied by myself on a tight schedule from 7:00 to 22:00 every day in those three weeks. And then we had the first monthly exam and I came first in the grade, exceeding the second-place student by forty or fifty points. I kept the position and the large gap (to second place) in every exam afterwards. Many students might say Year 3 (in senior school) was difficult but I felt it was very smooth.

A similar description of the strategies of working-class high-achievers and their industry, self-discipline, dedication and single-minded application is offered by Bourdieu and Passeron (1990) and by Reay and her colleagues (2009). Compared with middle-class students whose academic success largely depends upon family support both in a practical sense, such as private tuition, and more generally in the transfer of cultural capital (Ball 2003), the education success of working-class high-achievers comes almost entirely from their individual striving. This is undertaken with little access to relevant forms of cultural capital, as noted by Reay and her colleagues $(2009,1109)$, because 'they have had to focus so intently on achieving academic success in their chosen field that they have foregone wider cultural accomplishments and they are open about their efforts'. This focus on performance both impoverishes their educational experience and more than middle-class students subjects them to the limitations of meritocratic discipline. The risk is that when they enter an environment where performance is no longer a guarantee of 'success', they lose their sense of purpose and the ability to succeed. We will consider some of the risks in relation to their strategy in the next section. 
The hard work of the students evident in this study does not only mean industry, determination and self-discipline, but also includes abilities such as critical self-evaluation, reflexivity, strategy and efficiency. These reflexive dispositions can be seen from the example of Yifan Yang's account:

I think I was flexible. When I used a strategy, I would wait and see its result, whether it could work, and then I would think about reasons and make adjustments accordingly. I went for high-efficiency. If a strategy didn't work, I would think about the reasons and try to figure out how I could make it better. I would keep thinking of it until I could have a better strategy.

Although the importance of 'flexibility' is only reported explicitly by a few participants, it is implicit in almost every account, including $\mathrm{Da}$ Tang, who is from a remote village and describes himself as 'dumb', 'single-minded' and 'stupid'. For example, at senior school, Da Tang refused the invitation to join the top class and chose to stay in the second-best class as he saw 'they (students in the top class) all looked very stressed' and 'I didn't want to be so stressed'. And 'the teachers in the second best class could also give you extra exercises and training and if you achieved in the second best class, you could also be in the top ten in the whole school'. He also demonstrated 'flexibility' in managing his time before the Gaokao (National College Entrance Exam in China). 'I submitted blank exam papers in the third or fourth mock exams before the Gaokao (often the fourth mock exam is held a week before the Gaokao). I preferred to have more time reading. Teachers would not mark our papers. They didn't have time to look at our papers at that time.' In both respects, Da Tang demonstrates a sophisticated sense of strategy and tactics in relation to his academic work. He becomes adept at ensuring high levels of support and avoiding too much stress. He picks his way through the school system with great care and acquires a detailed knowledge of how things work and how to benefit from school systems and practices. 
Similarly reflexive dispositions are noted by Reay and her colleagues (2009) in their study of nine working-class students at an elite university. These reflexive dispositions become embedded in the habitus of the working-class high-achievers through their early school experiences. The working-class students in their study (Reay, Crozier, and Clayton, 2009) who experienced dislocations in working-class schooling developed a set of dispositions, 'resilience', 'an ability to cope with adversity' and a 'self-reliant independence' (1107), which enabled them to deal with the adversity they encountered in elite universities. In a way similar to the participants in Reay and her colleagues' study, the reflexive dispositions our respondents developed early in their life, provide personal resources on which they could draw to deal with the challenges and difficulties they encountered at university (see Authors 2019a). However, contrary to Reay and her colleagues'study, the reflexive dispositions of the participants in our study do not help them to retain 'key valued aspects of working-class self' (Reay, Crozier, and Clayton 2009, 1111). Rather, these reflexive dispositions, as shown by Yifan Yang's account, relate to and are narrowly focused on maintaining high levels of academic performance. Reflexivity is a key aspect of their academic competency. This difference may partly be explained by the effects of 'declassing' that stem from the singular focus on exam performance in the field of Chinese schooling (see the next section).

Working-class students can achieve academic success, but the strategy they use has the effect of distancing and distinguishing them from middle-class students. The field of key schools, which will be discussed in the following section, reinforces this distancing.

\section{Schools: reinforcing distancing}

'Key secondary schools' were first introduced by the Chinese government in 1953 in order to concentrate resources in a situation where finances were extremely limited (Liang, Zhang, 
and Li 2013, 218). It was intended that through the key school policy, a small number of good schools would be built and subsequent to this the quality of normal schools would be improved through cooperation. However, the policy resulted in a sharp divide and marked inequality between key schools and normal schools. In 2006 the key school policy was abandoned by the Chinese government, as announced in the new Compulsory Education Law, but the structure of 'tiered schooling' has been retained.

Under the framework of 'tiered schooling', key senior secondary schools control access to elite universities (e.g., Liu, Wang, and Yang 2012; Postiglione et al. 2017). 12 of our respondents came from city-based key secondary schools although only four respondents in our study were city-born, and the other five participants all went to key schools in their localities. Within this system meritocracy and declassing are the essential features of education practices, as shown by Figure 2 .

[Insert Figure 2 here]

\section{Meritocracy at schools: 'exam factory'}

The meritocratic structure in Chinese schooling is formed by the effects of two major examinations - senior school entrance examination and Gaokao. Success in the first examination is a premise for achieving success in the second examination, as almost only key schools under the framework of 'tiered schooling' can offer adequate preparation for Gaokao. Through the effects of these two major entrance examinations, what is envisaged as a meritocratic structure drives not only the practice at senior secondary schools but also the practice in primary schools and junior secondary schools as well-illustrated by Juan Du:

I had a good performance in primary school, so the teachers in the primary school recommended me to a junior school in the town (she lived in the village), which was the best junior school in the locality. That junior school was really good and then I went to 
the best senior school in the city, based on my performance in the entrance examination. There were different kinds of classes in the senior school - high-achieving classes and normal classes. Many in the high-achieving classes were my junior school classmates. So if I didn't go to that junior school, it would be very difficult for me to enter that senior school. Then I would not enter this university either. If I didn't go to this university, I would not think of going abroad for further studies.

In this way, Chinese schooling is a step-by-step selection process that is based on and continually orientated towards exam performance. This underwrites teachers' relations with students and students' orientation towards performance, articulated within monthly examinations and corresponding rankings. Through monthly rankings, the worth and the competitiveness of a student is made clear by his/her position and over time in relation to these rankings students reflect on their performances, develop strategies, adjust their ambitions, and regulate themselves. The cultivation of self-discipline through ranking is evident in every participant's narrative, as shown in Da Tang's account:

I was once eight hundredth. I didn't think about Tsinghua or Peking. I didn't dare to. The ideal situation for me would be a key university. I didn't dare to think more. After I went to the sciences track (students were divided into the sciences track and the humanities track after Year 1 at senior school), I entered the top 50 in the grade! I was astonished, how come I could make such a huge progress? I began to see a future. Then I suddenly became the first in my class and I kept that position afterwards. Later I got into the top ten in the school. I worked really hard. I climbed into the classroom every day at 5:20am from the window I left open the day before because the school gate only opened at 5:50 am. My only thought at that time was Gaokao.

Constant monitoring contributes, for those who are successful in tests and examinations, to the development of flexibility, reflective thinking, independence and self-discipline. Young (1958) described the condition for the full form of meritocracy, 'it is that a meritocracy could only exist in any full form if there were such a narrowing down of values that people could be 
put in rank order of worth' (xvii). The values in Chinese schooling are narrowed in just this way and exam performance becomes the sole basis for ranking and selection.

In effect, a synthesis develops between the habitus of working-class high-achievers and the field of Chinese schooling. Performance is the single thing they pursue; meritocracy is the philosophy they believe in; and individualised hard work is the strategy they use and promote. In some respects, this synthetic habitus of working-class high-achievers is more specific and highly developed than that of middle-class high-achievers. With no alternative, working-class students have to accept the disciplines of school life as they strive to distance themselves from their class origins. For them, this is a 'change or die' choice (Hurst 2010). In contrast, middle-class high-achievers are less driven by the necessities of performance and their success draws both on the involvement of their families and individual effort.

As Bourdieu (1990) explains in the following quote (57-58) in relation to how the synthesis between habitus and field contributes to the maintenance and reinforcement of class domination, meritocracy becomes 'complete and fully viable' through being 'durably objectified' this is evident not only in 'the logic' of Chinese schools but also on 'bodies' of these working-class high-achievers. The students' commitment to meritocracy as a view of 'how the world works' - hard work always pays off - and individualism as its concomitant a way of being in the world are both strengthened through socialisation at school and reinforced through 'successes' in the education field. Also through their choices and tactics these working-class high-achievers enact and embody the objectification of the field. They inherit meritocracy, appropriate it practically, revise it and reactivate it. These working-class high-achievers become 'an eldest son, an heir, a successor' (Bourdieu 1990, 58) of meritocracy who is obliged to make and keep meritocracy in constant activity and in complete function. 
...through which agents partake of the history objectified in institutions, is what makes it possible to inhabit institutions, to appropriate them practically, and so to keep them in activity, continuously pulling them from the state of dead letters, reviving the sense deposited in them, but at the same time imposing the revisions and transformations that reactivation entails...An institution, even an economy, is complete and fully viable only if it is durably objectified not only in things, that is, in the logic, transcending individual agents, of a particular field, but also in bodies, in durable dispositions to recognise and comply with the demands immanent in the field.

These students embody the objectification of the institutions and logic of meritocracy. Their 'improvised' habitus continuously revalidates meritocracy and individualism in the field of Chinese schooling in ways 'more reliable than all formal rules and explicit norms' (Bourdieu 1990, 54). They reap the rewards, but at the same time suffer the damage inflicted by the necessities of single-minded hard work and the exclusion of other possibilities for their sense of self and personal wellbeing.

\section{Declassing: reinforcing distancing}

Socialisation and experiences at school not only reinforce meritocratic dispositions at the level of habitus; they also involve a process of declassing, as seen in Ye Lin's account:

I asked the president of our students' union on how to improve my social skills. It was a main concern to me. I didn't know how to talk and how to get in touch with others. He said: 'You don't need to worry about that. Are you worrying about your studies?' 'No, not at all. I am the second in my grade. I have no reason to worry about my studies.' Then he said: 'You are young. You shouldn't worry about your social ability at all. All you need to do is to concentrate on you studies. It will be fine'. I thought he was cold. $\mathrm{He}$ didn't give me any advice. However, after Gaokao, I found people coming to me automatically, even junior school classmates getting back in touch with me. It was really like 'The person who can manage the state by means of his virtue is like Polaris, which stays in its place and all stars turn around it' (a sentence from the Confucian Analects). When you are good enough (in studies), people will come to you automatically, because you are a person who is worth being around. 
These young people attract others, as they are 'worth' being around and meritocracy creates the illusion that class does not matter and can be transcended by performance. Once you are high-achieving, you have 'worth' and you are judged by your performance rather than by class.

The declassing process is also strengthened by the boarding experience of some of our respondents. Eight participants had boarded since junior school and 12 participants boarded at senior school. Boarding at school for these students means geographic and also social separation from their parents and working-class community. Through years of separation, their relations with parents, and with working-class localities, become 'blurred' and distant, as described by Yun Jiang:

I drifted apart from my parents since senior school. In the first two years, I went back home once a week and in the last year I only went back once a month. I felt since then a gulf began to develop with my parents. They had not been in my life for eight years. It was difficult to imagine how I could talk to them about my job. I tried to, but there were so many gaps between us. It was very difficult. Some people might think their parents were their most important support, but for me, since senior school, bonds with family became really blurred.

As commented by Liu and her colleagues $(2012,52)$, in the refashioning of working-class students' habitus, 'parents are absent' and 'the role of secondary schools is greater than that of households'. Liu and her colleagues refer to working-class high-achievers as 'institutional children' (2012, 52). Socialisation at these boarding schools has features resembling what Goffman (1961) calls a ‘total institution' where people sleep, play and work in the same place, with the same group of similar people, under the same tight schedule and a 'single overall rational plan purportedly designed to fulfil the official aims of the institution' (6). The 'official aim' in the 'total institution' of Chinese key schools is simple and direct - 'exam performance' and the 'moral career' of the students as 'high-achievers' is begun in these 
'total institutions'. However, the tight focus on a 'single overall rational plan' and the refashioning of habitus that ensues is enabling and limiting at the same time. It does not, as it turns out, prepare the students for entry into the middle class while it does distance them from the working class.

Their striving for distinction, with a single focus on exam performance and eschewing of personal interests and broader social and cultural competencies, is indeed 'the opposite of distinction' (Reay, Crozier, and Clayton 2009, 1109). Music classes and art classes are commonly reported by our respondents as having been replaced by maths or English. Their accounts of schooling are almost exclusively about exam performance and class rankings with very little or no mention of cultural activities and personal hobbies. Refashioned in a performance-centred environment, the very particular dispositions of these working-class students lead later to 'culture discontinuity' (Liu, Wang, and Yang 2012, 52) when they enter HE with its greater cultural diversity. Their difference from middle-class students and the differences in their school experiences become evident when they enter university. They experience a strong sense of inadequacy, inferiority, incompetence, and deficit and must confront the gap between the reality of university life and the 'imagined future' (Ball 2003) fostered by their success at school (see the details in Authors 2019a).

However, the risks of 'cultural discontinuity' are not apparent at school. At least to some extent these students enjoy their academic success and their experience as 'fish in water'. As described by Jia Peng in the previous section, 'many students might say Year 3 (in senior school) was difficult but I felt it was very smooth'. In this sense, their school experiences are debilitating. While almost every participant in our study spent considerable time exploring other interests and cultural activities not connected to exam preparation when they arrived at university, most of them (with only three exceptions as a 'transcending group' who we discussed in Authors 2019b) reported that they found little interest in anything that is 
not 'functional'. They are used to a life in pursuit of serious things and of striving for 'excellence' within which time for breaks, entertainment and leisure are regarded as 'bad habits' (Ping Wang), 'luxuries' (Xiao Li) and 'a waste of time' (Zhen Liang). Working hard and working for 'excellence' is regarded as the only authentic way of living. It is exactly those efforts and resources that have served to get them to university, enabled them to leave behind their working class origins, and represent the possibility of class mobility, but it is these resources that also produce and reinforce their difference from the middle-class students and middle-class destinations they are working towards. They experience 'cultural discontinuity' in both class directions and occupy an isolated and fragile position - a 'third class'. For most of our respondents, this is not an interim or transitional position rather their elite university experience and employment choices reinforce their liminality (see Authors 2019a); the consequences of school discipline and their subjection to meritocracy and class domination are 'hidden injuries' and costs (Sennett and Cobb 1972) they will struggle with for the rest of their life.

Through socialisation at the total institutions of exam factories, the lives and aspirations of these academically successful working-class students are underpinned by the illusions of meritocracy; they adopt meritocracy as their worldview and become meritocratic agents. In some senses this serves them well, but at the same time they are damaged and deceived by these illusions. These particular class injuries are to a certain extent 'selfinflicted', they are the injuries of striving and of success. When these students enter the social field of higher education with its greater cultural diversity and diversity of relevant capitals, their illusions are shattered, class returns to confront them, and class inequalities are manifest in new and more subtle ways. 


\section{Conclusion: welcome to the great country of meritocracy}

By focusing on a small group of working-class students who gained access to elite university education through their talent and effort in a prime meritocratic environment, this study has sought to problematise the relations between meritocracy and social justice and social mobility.

Our findings indicate what has been foregone by these students as they seek to achieve a certain degree of upward social mobility by means of their practically proven exceptional 'merit'. These students are chosen by the meritocratic system, and disciplined, fostered, produced and reproduced by it. Our findings demonstrate how their experience of education, their sense of themselves, their identity, self-worth, their possibilities and impossibilities are formed and forged and curtailed and distorted by meritocracy in action. In their trajectory to achieving academic success and to building their exceptionality, in their access to elite schools at every level and as they enjoy the opportunities, resources and privileges of being successful, exceptional and deserving, they are distancing themselves, geographically, socially, ideologically and morally, from their working-class localities and histories of origin. The system of meritocracy and the students themselves in effect construe the working-class community that is left behind as deficient and as undeserving. These working-class exceptions distance themselves and are distanced by their own successes and strivings from the 'ontological security' (Lehmann 2013, 12) of class belonging.

On the one hand, the system of meritocracy enables these working-class highachievers to 'escape' from their working-class origins, but it also makes and marks them as different from middle-class students, in terms of the opportunities and lifestyles they seek to achieve and emulate. As suggested by this paper, the experience of education of these 'exceptional' students is founded in a synthetic habitus that is both flexible and fragile - a habitus without history, the dispositions of which are narrowly defined by hard work, striving 
and giving up. What they bring with them is a set of cultural absences, and opportunities foregone for the sake of opportunity. Their class origins, in the particular form of their meritocratic agency, will come back to haunt them at university. Their acquired dispositions are ill-attuned to the social and cultural diversity and complexity of university life (as Authors 2019a and other studies have indicated). Their differences, limitations and inadequacies will become readily apparent in their daily life at university. These are class injuries and forms of symbolic domination which are in some respects self-inflicted, but they are also a consequence and an effect of the meritocratic game in action and its illusio (Bourdieu and Wacquant 1992). Class domination is not transcended by these working-class exceptions, but operates on them in a new and subtle form, which is achieved by meritocratic discipline.

The meritocratic skills and competencies they acquire leave these working-class survivors, in several respects, ill-equipped to benefit from what the elite university has to offer. Indeed, as rewards for their deferred gratification, for many, the elite university offers few gratifications. In a sense they find themselves 'in' but not 'of' the university. The widening participation agenda rests on the assumption that the challenge is to bring the (nontraditional) working-class student to the university and thus to open them up to new life experiences, perspectives, values and dialogues. As Reay and her colleagues concluded in their study, 'elite universities need non-traditional students just as much as the students need them', that is 'both need the other in order to flourish, the students academically and the universities socially' $(2009,1116)$. However, as shown by this paper, as meritocratic subjects, students of working class origin do not bring their working classness with them, they bring their hard work, their individualism and their class injuries. Their ability to contribute to or transform the university is limited. These working-class survivors will contribute only symbolically to agendas of 'widening participation' but are unable to contribute substantively. 
As a 'third class', neither working- nor middle- class whose core values reside in meritocracy itself, these working-class exceptions may be more likely to fulfil their obligations as meritocratic subjects, to build a more advanced meritocratic society, continuously reactivating and reproducing it, leaving class domination and the reproduction of inequality unchallenged.

\section{References:}

Authors. 2019a. "Precarious Success and the Conspiracy of Reflexivity: Questioning 'Habitus Transformation' of Working-class Students at Elite Universities." Details omitted for peer review.

Authors. 2019b. "'Toned Habitus', Class Transcendence and the Contingency of Reflexivity: A Life Story Study of Working-class Students at Elite Universities in China." Manuscript submitted for publication.

Ball, S. J. 2003. Class Strategies and the Education Market: The Middle Classes and Social Advantage. London: Routledge.

Ball, S. J. 2011. "Social Class, Families and the Politics of Educational Advantage: The Work of Dennis Marsden." British Journal of Sociology of Education 32(6): 957-965.

Bell, D. 1973. The Coming of Post-industrial Society. New York: Basic Books.

Bourdieu, P. 1984. Distinction. London: Routledge and Kegan Paul.

Bourdieu, P. 1990. The Logic of Practice. Cambridge, UK: Polity Press.

Bourdieu, P. 1996. The State Nobility: Elite Schools in the Field of Power. Cambridge, UK: Polity Press.

Bourdieu, P. 1999. The Weight of the World: Social Suffering in Contemporary Society. Cambridge, UK: Polity Press.

Bourdieu, P., and J. C. Passeron. 1990. Reproduction in Education, Society and Culture. $2^{\text {nd }}$ ed. London: Sage. 
Bourdieu, P., and L. D. Wacquant. 1992. An Invitation to Reflexive Sociology. Chicago: University of Chicago Press.

Brown, P. 2009. "Education, Meritocracy and the Global War for Talent." Journal of Education Policy 24(4): 377-392.

Brown, P. 2013. "Education, Opportunity and the Prospects for Social Mobility." British Journal of Sociology of Education 34(5-6): 678-700.

Dench, G., ed. 2006. The Rise and Rise of Meritocracy. London: Blackwell.

DfE (Department for Education), PMO (Prime Minister's Office) and T. May. 2016. "Britain, the Great Meritocracy: Prime Minister's Speech." GOV. UK, September 9. https://www.gov.uk/government/speeches/britain-the-great-meritocracy-prime-ministersspeech.

Goffman, E. 1961. Asylums: Essays on the Social Situation of Mental Patients and Other Inmates. Garden City, NY: Anchor Books.

Granfield, R. 1991. "Making it by Faking it: Working-class Students in an Elite Academic Environment." Journal of Contemporary Ethnography 20(3): 331-351.

Halsey, A.H., ed. 2007. Democracy in Crisis? Ethical Socialism for a Prosperous Country. London: Politico.

Hurst, A. L. 2010. The Burden of Academic Success: Loyalists, Renegades, and Double Agents. Lanham: Lexington Books.

Karabel, J. 2005. The Chosen: The Hidden History of Admission and Exclusion at Harvard, Yale and Princeton. Boston: Houghton Miffen Company.

Lehmann, W. 2013. "Habitus Transformation and Hidden Injuries: Successful Working-class University Students." Sociology of Education 87(1): 1-15.

Li, H. 2013. "Rural Students' Experiences in a Chinese Elite University: Capital, Habitus and Practices." British Journal of Sociology of Education 34(5-6): 829-847. 
Liang, C., H. Zhang, and Z. Q. Li. 2013. Wusheng De Geming [Silent Revolution: A Study of Students' Social Origins at Peking University and at Suzhou University from 1949 to 2002]. Beijing: SDX Joint Publishing.

Liu, Y. S., Z. M. Wang, and X. F. Yang. 2012. "Selecting the Elite: Status, Geography and Capital-Admission of Rural Students into Peking University (1978-2005)." International Journal of Chinese Education 1(1): 19-53.

Lu, X. Y. 2002. Dangdai Zhongguo Shehui Jie'ceng Yanjiu Baogao [A Report on the Social Classes in Contemporary China]. Beijing: Social Sciences Academic Press.

Norman, R. 1987. Free and Equal. Oxford: Oxford University Press.

Postiglione, G, A. L. Xie, J. S. Jung, and Y. B. Hong. 2017. "Rural Students in a Chinese Top-Tier University: Family Background, School Effects, and Academic Performance." Chinese Education \& Society 50 (2): 63-74.

Radnor, H., V. Koshy, and A. Taylor. 2007. "Gifts, Talents and Meritocracy." Journal of Education Policy 22(3): 283-299.

Reay, D. 1998. Class Work: Mothers Involvement in Their Children's Primary Schooling. London: Routledge.

Reay, D., G. Crozier, and J. Clayton. 2009. "'Strangers in Paradise'?: Working-class Students in Elite Universities." Sociology 43(6): 1103-1121.

Sayer, A. 2005. The Moral Significance of Class. Cambridge, UK: Cambridge University Press.

Sennett, R. and J. Cobb. 1972. The Hidden Injuries of Class. Cambridge: Cambridge University Press.

Thornberg, R. 2012. "Informed Grounded Theory." Scandinavian Journal of Educational Research 56(3): 243-259. 
Wacquant, L. J. D. 1993. "From Ruling Class to Field of Power: An Interview with Pierre Bourdieu on La Noblesse d'État." Theory, Culture \& Society 10(3): 19-44.

Xie, A. (2016). "Rural Students in China's Elite Universities: Social Mobility and Habitus Transformation. [In Chinese.] Educational Research no.11: 74-81.

Young, M. D. 1958. The Rise of the Meritocracy. New Brunswick, NJ: Transaction Publishers.

Young, M.D. 2001. "Down with Meritocracy.” The Guardian, June 29.

http://www.guardian.co.uk/politics/2001/jun/29/comment 